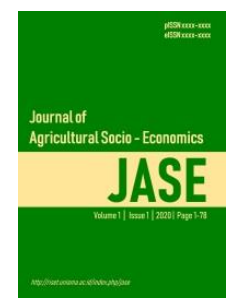

\title{
Efisiensi Teknis Penggunaan Input Produksi Pada Usahatani Sawi (Kasus Desa Baumata, Timur Kecamatan Taebenu Kabupaten Kupang, NTT)
}

\author{
Salsabila L. Murdolelono, Maximilian M. J. Kapa*, Maria Bano \\ Fakultas Pertanian, Universitas Nusa Cendana Kupang \\ E-mail: maximilian.kapa@staf.undana.ac.id
}

\begin{abstract}
This study aims (1) to analyze the influence of the use of production factors on the amount of mustard production; (2) to analyze the technical efficiency of the use of production inputs in mustard farming in the research area; and (3) to analyze the feasibility of mustard farming in the research area. Determination of the sample of respondent farmers using the method of saturated samples because the members of the population is small (41 people). So the number of respondents was as many as 41 farmers. The results showed that the use of land area input (x1), seeds (x2), organic fertilizers (x3), inorganic fertilizers (x4), pesticides (x5), and labor (X6) simultaneously had a significant effect on mustard production $(\alpha=0.05)$, as evidenced by the value of $\mathrm{F}$-stat of 441,015 greater than $F$ table of 2.49. Partially the production factor that has a very significant effect $(\alpha=0.01)$ on the increase in mustard production is the land with a regression coefficient of 0.082 and a t-stat value of 8,396 , seeds have a real effect $(\alpha 0.05)$ on mustard production with a regression coefficient value of 0.082 and a $t$ count value of 3,075 and inorganic fertilizers have a noticeable effect $(\alpha=0.10)$ on mustard production with a regression coefficient value of 0.065 and a $t$ stat value of 2.125 . While other production factors, namely organic fertilizers, pesticides and labor have no real effect on the production of mustard at the research site. The Coefficient of Determination (R2) obtained a value of 0.994 which means that $99,4 \%$ of the dependent variable was expamimed by the independent variables while the remaining $0.6 \%$ is explained by other variables that are not included in the model. The use of production factors such as land area, seeds, organic fertilizers, inorganic fertilizers and labor in mustard farming was technically efficient, because the value of $b>0$. This can be seen from the coefficient of regression of each variable, namely land area (0.395), seeds (0.082), organic fertilizers (0.079), inorganic fertilizers $(0.395)$ and labor $(0.002)$. While the pesticide input production in mustard farming is technically inefficient, because the value of $b<0$. This can be seen from the value of pesticide regression coefficient of -0.035 . Mustard farming at the research site provides relative profit with the value of $\mathrm{R} / \mathrm{C}$ Ratio $>1(\mathrm{R} / \mathrm{C}=3.65)$ so that mustard farming is feasible to be cultivated.
\end{abstract}

Keywords: Production factors, technical efficiency, mustard farming, relative profit

Abstrak. Penelitian ini bertujuan untuk (1) menganalisis pengaruh penggunaan faktor produksi terhadap jumlah produksi sawi (2) menganalisis tingkat efisiensi teknis penggunaan input produksi pada usahatani sawi di daerah penelitian; dan (3) menganalisis kelayakan usahatani sawi di daerah penelitian. Penentuan sampel petani responden menggunakan metode sampel jenuh karena jumlah anggota populasi kecil (41 orang). Sehingga jumlah responden yaitu sebanyak 41 petani. Hasil penelitian menunjukan bahwa, penggunaan faktor produksi luas lahan (X1), benih (X2), pupuk organik (X3), pupuk anorganik (X4), pestisida (X5), dan tenaga kerja (X6) secara serempak berpengaruh nyata terhadap hasil produksi sawi $(\alpha=0,05)$, yang dibuktikan oleh nilai $\mathrm{F}$ hitung diperoleh nilai sebesar 441,015 lebih besar dari F tabel sebesar 2,49. Secara parsial faktor produksi yang berpengaruh sangat nyata $(\alpha 0,01)$ terhadap peningkatan produksi sawi adalah luas lahan dengan koefisien regresi 0,082 dan nilai $t$ hitung 8,396 , benih berpengaruh nyata $(\alpha=0,05)$ terhadap produksi sawi dengan nilai koefisien regresi 0,082 dan nilai $t$ hitung 3,075 dan pupuk anorganik berpengaruh nyata $(\alpha=0,10)$ terhadap produksi sawi dengan nilai koefisien regresi 0,065 dan nilai t hitung 2,125 . Sedangkan faktor produksi lainnya yaitu pupuk organik, pestisida dan tenaga kerja tidak berpengaruh nyata terhadap produksi sawi di lokasi penelitian. Koefisien Determinasi (R2) diperoleh nilai sebesar 0,994 yang artinya bahwa kemampuan variabel-variabel bebas untuk menjelaskan variabel terikat yakni sebesar 99,4\% sedangkan sisanya $0,6 \%$ dijelaskan oleh variabel lain yang tidak dimasukan dalam model. Penggunaan faktor-faktor produksi seperti luas lahan, benih, pupuk organik, pupuk anorganik dan tenaga kerja 
dalam usahatani sawi secara teknis telah efisien, karena nilai $b>0$. Hal ini dapat dilihat dari nilai koefisien regresi dari masing-masing variabel yakni luas lahan $(0,395)$, benih $(0,082)$, pupuk organik $(0,079)$, pupuk anorganik $(0,395)$ dan tenaga kerja $(0,002)$. Sedangkan faktor produksi pestisida dalam usahatani sawi secara teknis tidak efisien, karena nilai $\mathrm{b}<0$. Hal ini dapat dilihat dari nilai koefisien regresi pestisida yaitu $-0,035$. Usahatani sawi di lokasi penelitian memberikan keuntungan relatif dengan nilai R/C Ratio > 1 yakni 3,65 sehingga usahatani sawi layak untuk diusahakan.

Kata Kunci: Production factors, technical efficiency, mustard farming, relative profit

\section{PENDAHULUAN}

Sektor pertanian merupakan sektor penting pendukung perekonomian masyarakat Indonesia. Sektor ini berkontribusi dalam meningkatkan pendapatan dan taraf hidup petani dan memperluas kesempatan berusaha. Pembangunan sektor pertanian tidak hanya ditujukan untuk memantapkan swasembada beras dan palawija, tetapi juga mencakup usaha-usaha peningkatan produksi lainnya seperti dari holtikultura, peternakan dan perikanan (Tatu, 2011).

Salah satu sub sektor pertanian yang sangat potensial untuk dikembangkan adalah sub sektor holtikultura khususnya tanaman sayuran. Sayuran merupakan salah satu komponen dari menu makanan yang sehat, maka tidak heran bila kebutuhan sayuran semakin meningkat sejalan dengan kesadaran masyarakat tentang kesehatan. Di antara bermacam-macam jenis sayuran yang dapat dibudidayakan, tanaman sawi (Brassica Juncea L.) merupakan salah satu komoditas sayuran yang memiliki nilai komersial dan prospek yang tinggi dan sangat terkenal di kalangan konsumen, karena rasanya yang mudah diterima oleh lidah konsumen.

Provinsi Nusa Tenggara Timur menurut data statistik pertanian pada tahun 2018 menghasilkan sawi sebanyak 10.075 ton per ha, terdapat kenaikan produksi sebesar $16,4 \%$ dari tahun sebelumnya (Statistik Tanaman dan Sayuran Provinsi NTT, 2017-2018). Di lain pihak Kabupaten Kupang pada tahun 2017 mampu menghasilkan sawi sebesar 8,654 ton per ha. Hal ini menunjukan bahwa Kabupaten Kupang berkontribusi signifikan terhadap penyediaan sayur sawi bagi masyarakat NTT khususnya masyarakat Kota Kupang dan Kabupaten Kupang.

Kecamatan Taebenu di Kabupaten Kupang merupakan salah satu sentra produksi sawi, karena didukung oleh keadaan tanah cukup baik dan sangat cocok untuk usahatani sawi, disamping itu Kecamatan tersebut juga memiliki sumber mata air, serta iklim yang sangat mendukung. Berdasarkan data yang diperoleh dari Badan Pusat Statistik Kabupaten Kupang menjelaskan bahwa rerata produksi sawi di Kecamatan Taebenu selama lima tahun terakhir menunjukan tren yang berfluktuasi. Di mana pada tahun 2014 produksi sawi 219,1 ton dengan luas panen sebesar $182 \mathrm{Ha}$, tahun 2015 produksi sawi turun menjadi 154,5 ton dengan luas panen tetap yaitu $182 \mathrm{Ha}$, tahun 2016 jumlah produksi sawi naik menjadi 292,5 ton meskipun terjadi penurunan luas panen yakni $166 \mathrm{Ha}$, tahun 2017 jumlah produksi tanaman sawi sebesar 293,6 ton dengan luas panen sebesar $123 \mathrm{Ha}$.

Berfluktuasinya produksi sawi di Kecamatan Taebenu kemungkinan besar disebabkan karena belum optimalnya penggunaan input-input produksi dan minimnya akses petani terhadap permodalan. Input-input produksi yang dimaksud adalah luas lahan, jumlah bibit, jumlah pupuk dan jumlah pestisida yang digunakan dalam budidiya sawi. Luas lahan yang digunakan dalam budidaya sawi mungkin saja tidak optimal sebagaimana diterangkan oleh data di atas. Ketika luas panen menurun maka rata-rata produksi sawi pun menurun, dan apabila luas lahan bertambah luas maka diikuti pula oleh kenaikan produksi. Namun asumsi ini tidak selamanya benar karena produksi usahatani selalu mengikuti hukum kenaikan hasil yang berkurang (The law of diminishing return), hal inilah yang menunjukan bahwa pengurangan atau penambahan penggunaan faktor produksi luas lahan misalnya belum tentu merupakan pilihan yang tepat.

Desa Baumata Timur merupakan salah satu desa yang terletak di Kecamatan Taebenu, Kabupaten Kupang. Masyarakat yang tinggal di desa Baumata Timur sebagian besar berprofesi sebagai petani. Terdapat beragam jenis tanaman yang diusahakan seperti tanaman pangan (jagung, padi dan kacangkacangan), serta beberapa jenis sayuran seperti sawi, kangkung, bayam dan lain-lain. Namun berdasarkan survei awal di lokasi penelitian masyarakat Desa Baumata Timur lebih dominan mengusahakan sayuran sawi dikarenakan tidak membutuhkan biaya yang besar dalam berusahatani sawi, benih lebih murah dari sayur lain dan komoditi ini mempunyai umur panen yang cepat sehingga 
dapat memberikan maanfaat yang besar bagi petani (Lama dan Kune, 2016). Jenis sawi yang dibudidayakan di Desa Baumata Timur rata-rata adalah sawi hijau. Jenis sawi ini memiliki rasa yang renyah dan gurih sehingga sangat disukai oleh masyarakat pada umumnya. Peningkatan produksi sawi akan dapat tercapai apabila penggunaan input-input produksi telah digunakan secara optimal (efisien). Namun apakah alokasi sumber daya (input) yang dilakukan petani telah mencapai tingkat efisiensi secara teknis? Pertanyaan inilah yang dijawab dalam penelitian ini.

Penelitian ini bertujuan: 1) Untuk mengetahui pengaruh penggunaan input produksi terhadap jumlah produksi pada usahatani sawi di daerah penelitian. 2) Untuk mengetahui tingkat efisiensi teknis penggunaan input produksi pada usahatani sawi di daerah penelitian, dan 3) Untuk mengetahui kelayakan usahatani sawi di daerah penelitian.

\section{METODE}

\subsection{Lokasi dan Waktu Penelitian}

Penentuan lokasi penelitian dilakukan dengan sengaja (purposive sampling) yakni pada Desa Baumata Timur Kecamatan Taebenu. Dengan pertimbangan bahwa lokasi tersebut merupakan wilayah yang mengembangkan usahatani sawi di Kecamatan Taebenu. Penentuan sampel petani sawi (responden) diambil dari populasi petani yang mengusahakan tanaman sawi di Desa Baumata Timur Kecamatan Taebenu.

\subsection{Jenis dan Sumber Data}

Data yang dikumpulkan pada penelitian ini terdiri dari data primer dan data sekunder. Data primer diperoleh dari hasil wawancara langsung kepada petani responden dengan menggunakan daftar pertanyaan (kuisioner) yang telah dipersiapkan. Data sekunder merupakan data pelengkap yang diperoleh dari studi pustaka (dengan menelaah buku-buku/perpustakaan) atau lembaga terkait yang berhubungan dengan penelitian.

\subsection{Metode Penentuan Responden}

Metode penentuan sampel yang digunakan dalam penelitian ini adalah metode sampel jenuh. Jumlah kelompok tani yang mengusahakan usahatani sayur sawi sebanyak 2 kelompok tani dengan jumlah populasi yaitu sebanyak 41 petani. Oleh karena populasinya kecil maka seluruh anggota populasi diambil sebagai responden yakni sebanyak 41 orang.

\subsection{Analisis Data}

Untuk menjawab tujuan pertama penelitian ini yaitu untuk melihat pengaruh input produksi terhadap produksi sawi terlebih dahulu diketahui model fungsi produki yang digunakan. Model fungsi produksi yang digunakan adalah fungsi produksi Cobb-Douglas, dengan rumus sebagai berikut (Tarigan, K. Dan L. Sihombing, 2007)

Fungsi produksi tersebut kemudian diubah menjadi bentuk fungsi regresi linear berganda dengan cara mentransformasikan persamaan tersebut ke dalam persamaan log natural (ln). Bentuk persamaan fungsi produksi menjadi:

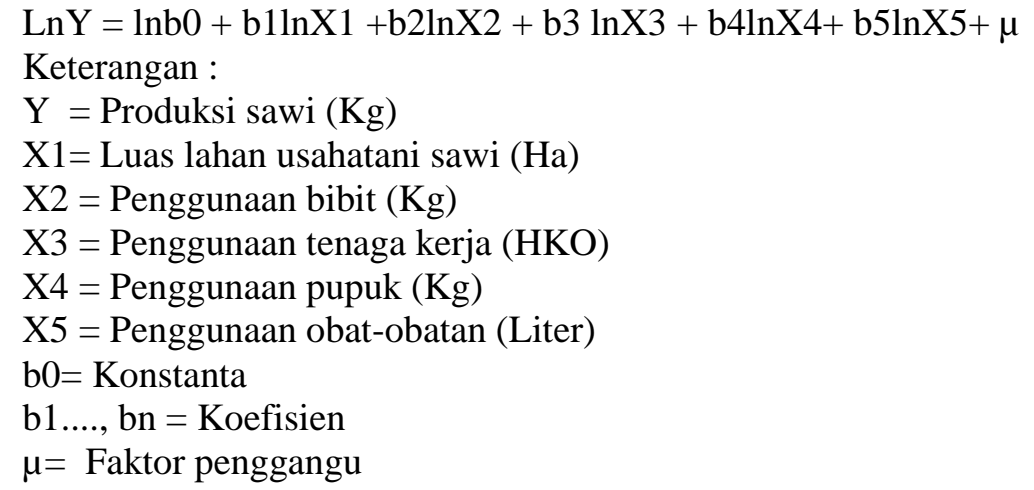

-Koefisien Determinasi (R2); Ketepatan model persamaan di atas diukur dengan koefisien determinasi (R2). Suatu penelitian atau observasi perlu dilihat seberapa jauh model yang terbentuk dapat menjelaskan kondisi yang sebenarnya, dengan menggunakan rumus: 


$$
R^{2}=\frac{\text { jumlah kuadrat regresi }}{\text { jumlah kuadrat total }}
$$

Bila nilai koefisien determinasi (R2) mendekati angka 1, maka variabel independen makin besar pengaruhnya terhadap variabel dependen sehingga dikatakan bahwa penggunaan model tersebut dapat dibenarkan. Dengan kata lain, koefisien determinasi (R2) digunakan untuk mengukur seberapa besar sumbangan dari variabel Xi terhadap variabel Yi.

- Uji Simultan (Uji-F);. Untuk mengetahui pengaruh input produksi (X) terhadap produksi (Y) secara simultan (bersama-sama) digunakan uji F. Adapun uji F dapat dihitung dengan persamaan sebagai berikut:

$$
=\frac{\text { kuadrat tengah regresi }}{\text { kuadrat tengah sisa }}
$$

Hipotesis statistik :

- $\quad \mathrm{H} 0: \mathrm{bi}=0$, tidak ada pengaruh variabel independen $(\mathrm{Xi})$ terhadap variabel dependen $(\mathrm{Y})$.

- $\quad \mathrm{H} 1:$ bi $\neq 0$, adanya pengaruh variabel independen (Xi) terhadap variabel dependen (Y).

Dengan ketentuan :

- Jika F hitung > F tabel, maka H0 ditolak. Artinya secara bersama-sama variabel independen (X) berpengaruh nyata terhadap variabel dependen (Y).

- Jika F hitung $\leq \mathrm{F}$ tabel, maka Ho diterima. Artinya secara bersama-sama variable independen (X) tidak berpengaruh nyata terhadap variabel dependen (Y).

- Uji Statistik t; Menurut Agustira (2004), untuk menguji apakah pengaruh bebas yakni input (Xi) yang digunakan dari usahatani sawi secara parsial berpengaruh nyata terhadap hasil produksi (Y) digunakan uji -t. Semua variabel bebas (Xi) diuji satu persatu. Hipotesis yang diajukan adalah:

$$
\begin{aligned}
& \mathrm{H} 0: \mathrm{bi}=0 \\
& \mathrm{H} 1: \mathrm{bi} \neq 0 \\
& t_{\text {hitung }}=\frac{b i}{\operatorname{Se}(b i)}
\end{aligned}
$$

Keterangan:

Hipotesis :

bi $=$ Koefisien Regresi

$\mathrm{Se}=$ Simpangan Baku

- $\mathrm{H} 0: \mathrm{bi}=0$, variabel independen $(\mathrm{X})$ berpengaruh tidak nyata terhadap variabel dependen $(\mathrm{Y})$.

- $\quad \mathrm{H} 1: \mathrm{bi} \neq 0$, variabel independen $(\mathrm{X})$ berpengaruh nyata terhadap variabel dependen $(\mathrm{Y})$

Dengan ketentuan :

- $\quad$ Jika $t$ hitung $>\mathrm{t}$ tabel, maka H0 ditolak. Artinya secara individu variabel idependen (X) berpengaruh nyata terhadap variabel dependen (Y).

- $\quad$ Jika t hitung $\leq \mathrm{t}$ tabel, maka H0 diterima. Artinya secara individu variabel independen (X) berpengaruh tidak nyata terhadap variabel dependen $(\mathrm{Y})$

Efisiensi Teknis : Untuk menjawab tujuan kedua yaitu untuk mengetahui tingkat efisiensi teknis penggunaan input produksi usahatani sawi dapat diketahui dari nilai b (koefisien regresi) dalam fungsi produksi Cobb-Douglas yang menggambarkan elastisitas produksi (Ep) (Soekartawi, 2003). Untuk mengetahui tingkat efisiensi secara teknis maka dapat ditentukan dengan kriteria:

- $\quad b<0$, maka faktor produksi tidak efisien secara teknis

- $\quad b>1$, maka faktor produksi belum efisien secara teknis

- $\quad 0 \leq \mathrm{b} \leq 1$, maka faktor produksi sudah efisien secara teknis

R/C Ratio : Untuk menjawab tujuan ketiga yakni untuk mengetahui besar nilai R/C ratio pada usahatani sawi, maka rumus yang dipakai adalah (Soeriatmadja, 1989) :

$$
\mathrm{R} / \mathrm{C}=\frac{\text { Revenue }}{\text { Cost }}
$$

Jika $\mathrm{R} / \mathrm{C}$ ratio $>1$ maka dikatakan usahatani menguntungkan, sedangkan jika $\mathrm{R} / \mathrm{C}$ ratio $<1$ maka usahatani dikatakan merugikan karena biaya yang dikeluarkan lebih besar dari penerimaan yang diperoleh. 


\section{HASIL DAN PEMBAHASAN}

\subsection{Karakteristik Responden}

Berdasarkan hasil penelitian karakteristik responden petani di Desa Baumata Timur dibagi dalam beberapa kategori, yaitu: umur responden, jenis kelamin, tingkat pendidikan, jumlah tanggungan keluarga, pengalaman berusahatani, luas kepemilikan lahan dan status kepemilikan lahan.

Umur Responden. Umur memiliki pengaruh secara fisik terhadap perilaku petani ketika menjalankan kegiatan usahataninya. Kemampuan fisik dari seorang petani dalam menjalankan kegiatan usahataninya memiliki pengaruh terhadap tingkat produksi dan produktivitas usahatani. Menurut Dakar (2016) petani dengan umur yang lebih muda memiliki kekuatan fisik yang jauh lebih besar daripada petani yang berumur lebih tua sehingga tingkat produktivitas kerjanya jauh lebih besar dan tinggi daripada petani yang berusia lebih tua. Semakin tua usia petani maka kemampuan fisiknya semakin menurun sehingga bisa menyebabkan menurunnya hasil produksi usahatani. Distribusi responden berdasarkan kelompok umur dapat dilihat pada tabel berikut:

Tabel 1. Distribusi Petani Responden berdasarkan Kelompok Umur di Desa Baumata Timur

\begin{tabular}{|c|c|c|c|}
\hline No & $\begin{array}{c}\text { Kelompok Umur } \\
\text { (Tahun) }\end{array}$ & Jumlah (orang) & Persentase (\%) \\
\hline 1 & $31-40$ & 18 & 45 \\
\hline 2 & $41-51$ & 11 & 26,8 \\
\hline 3 & $>51$ & 12 & 29,2 \\
\hline & Jumlah & $\mathbf{4 1}$ & $\mathbf{1 0 0}$ \\
\hline
\end{tabular}

Sumber: Data primer 2020 (diolah)

Berdasarkan tabel di atas, diketahui bahwa sebesar $45 \%$ petani responden di Desa Baumata Timur berumur 31-40 tahun dan 26,8\% petani berumur 41-51 tahun artinya hampir sebagian besar petani respoden berada pada usia kerja atau usia produktif, sedangkan sisanya yang berumur $>51$ tahun yaitu sebanyak 29,2 persen

Jenis Kelamin. Jenis kelamin secara tidak langsung dapat mempengaruhi usahatani. Petani dengan jenis kelamin perempuan cenderung kurang maksimal dalam melakukan kegiatan usahataninya karna kemampuan fisik petani lebih rendah di bandingkan laki-laki. Distribusi responden berdasarkan jenis kelamin dapat dilihat pada tabel berikut:

Tabel 2. Distribusi Petani Responden berdasarkan Jenis Kelamin di Desa Baumata Timur

\begin{tabular}{|c|l|c|c|}
\hline No & Jenis Kelamin & Jumlah (orang) & Presentase (\%) \\
\hline 1 & Laki-laki & 33 & 80,5 \\
\hline 2 & Perempuan & 8 & 19,5 \\
\hline & Jumlah & $\mathbf{4 1}$ & $\mathbf{1 0 0}$ \\
\hline
\end{tabular}

Sumber: Data primer 2020 (diolah)

Berdasarkan Tabel di atas diketahui bahwa petani laki-laki lebih banyak dibandingkan petani perempuan, laki-laki berjumlah 33 orang dengan presentase sebesar $80,5 \%$ dan perempuan berjumlah 8 orang dengan presentase sebesar $19,5 \%$. Keterlibatan perempuan dalam usahatani disebabkan petani perempuan sudah tidak memiliki suami, sehingga perempuan mengambil alih pekerjaan suami dalam mencukupi kebutuhan sehari-hari. Petani laki-laki lebih banyak karena mereka merupakan kepala keluarga yang mata pecahariannya sebagai petani dan kemampuan fisik laki-laki lebih kuat dibandingkan dengan perempuan.

Tingkat Pendidikan. Tingkat pendidikan secara langsung berhubungan erat dengan keadaan kualitas sumberdaya manusia pada suatu wilayah atau daerah. Menurut Dakar (2016) tingkat pendidikan yang tinggi pada suatu daerah diharapkan dapat membawa pengaruh atau berdampak positif terhadap pembangunan daerah terutama dalam mengadopsi inovasi yang ada. Sedangkan tingkat pendidikan yang 
rendah akan berdampak pada kemampuan daya serap terhadap inovasi pengembangan teknologi pada sektor pertanian. Distribusi responden berdasarkan tingkat pendidikan dapat dilihat pada tabel berikut:

Tabel 3. Distribusi Responden Berdasarkan Tingkat Pendidikan Formal di Desa Baumata Timur

\begin{tabular}{|c|c|c|c|}
\hline No & Pendidikan Formal & $\begin{array}{l}\text { Jumlah } \\
\text { (orang) }\end{array}$ & Presentase (\%) \\
\hline 1 & SD & 20 & 48,8 \\
\hline 2 & SMP & 12 & 29,3 \\
\hline 3 & SMA & 7 & 17,1 \\
\hline 4 & Sarjana & 2 & 4,8 \\
\hline & Jumlah & 41 & 100 \\
\hline
\end{tabular}

Sumber: Data primer 2020 (diolah)

Berdasarkan Tabel di atas, dapat kita lihat bahwa mayoritas petani di Desa Baumata Timur yaitu sebesar 48,8\% didominasi oleh lulusan Sekolah Dasar (SD), sedangkan sisanya berturut-turut lulusan SMP sebanyak 29,3\%, SMA $17,1 \%$ dan Sarjana 4,8\%. Hal ini akan mempengaruhi petani dalam menentukan keputusannya untuk menerima atau menolak sebuah inovasi.

Jumlah Tanggungan Keluarga. Jumlah tanggungan keluarga merupakan jumlah anggota keluarga yang harus ditanggung kelangsungan hidupnya oleh kepala keluarga. Menurut Dakar (2016) jumlah anggota keluarga memiliki pengaruh terhadap motivasi kerja dari petani sebagai kepala keluarga untuk meningkatkan pendapatan dan tingkat kesejahteraan anggota keluarganya. Jumlah anggota keluarga mempengaruhi proses pengambilan keputusan untuk kelangsungan usahatani dari seorang petani. Jika salah dalam mengambil keputusan maka akan berdampak pada kegiatan usahataninya. Distribusi responden berdasarkan jumlah tanggungan keluarga dapat dilihat pada tabel berikut:

Tabel 4. Distribusi Petani Responden berdasarkan jumlah tanggungan keluarga di Desa Baumata Timur

\begin{tabular}{|c|c|c|c|}
\hline No & $\begin{array}{c}\text { Tanggungan keluarga } \\
\text { (jiwa) }\end{array}$ & Jumlah (orang) & Persentase (\%) \\
\hline 1 & $1-3$ & 6 & 14,6 \\
\hline 2 & $4-6$ & 35 & 85,4 \\
\hline & Jumlah & $\mathbf{4 1}$ & $\mathbf{1 0 0}$ \\
\hline
\end{tabular}

Sumber: Data primer 2020 (diolah)

Berdasarkan Tabel di atas, diketahui bahwajumlah tanggungan keluarga petani responden yang terbesar ada pada kelompok 4-6 orang sebesar 35 orang atau 85,4 persen sedangkan 14,6 persen lainnya memiliki tanggungankeluarga antara 1-3 orang.

Pengalaman Berusahatani. Pengalaman berusahatani merupakan salah satu faktor yang mempengaruhi produksi usahatani. Semakin tinggi tingkat pengalaman berusahatani maka semakin baik pula pengelolaan usahataninya (Lilis, 2009). Kemampuan dan keahlian seorang petani dalam mengelola usahataninya ditentukan dengan pengalaman dalam berusahatani selama bertahun-tahun. Tingkat pengalaman berusahatani responden dapat di lihat pada tabel dibawah ini:

Tabel 5. Distribusi Petani Responden berdasarkan pengalaman berusahatani di Desa Baumata Timur

\begin{tabular}{|c|c|c|c|}
\hline No & Pengalaman Berusahatani (tahun) & Jiwa & Presentase (\%) \\
\hline 1 & $5-15$ & 15 & 36,59 \\
\hline 2 & $16-25$ & 17 & 41,46 \\
\hline 3 & $>25$ & 9 & 21,95 \\
\hline & Jumlah & $\mathbf{4 1}$ & $\mathbf{1 0 0}$ \\
\hline
\end{tabular}

Sumber: Data primer 2020 (diolah)

Berdasarkan Tabel di atas, diketahui bahwa sebanyak 36,59\% petani responden mempunyai pengalaman berusahatani 5-15 tahun, 41,46\% responden berpengalaman 16-25 tahun, sedangkan sisanya sebanyak $21,95 \%$ mempunyai pengalaman berusahatani $>25$ tahun. Petani dengan pengalaman berusahatani yang semakin besar akan lebih bijaksana dalam menentukan masa produksi, penggunaan saprodi atau sarana produksi pertanian dan sistem pengolahan usahataninya. 
Luas Lahan Usahatani. Menurut Dakar (2016), luas lahan pertanian merupakan salah satu faktor yang secara langsung dapat mempengaruhi tinggi rendahnya produksi pertanian. Ukuran luas lahan yang dimiliki petani akan berdampak pada produksi yang akan diperolehnya. Semakin luas lahan yang dikelola maka petani semakin giat mencari metode baru agar bisa memperoleh pendapatan yang lebih tinggi dengan biaya yang lebih ringan. Luas lahan dalam penelitian ini adalah luas lahan yang digunakan petani untuk mengusahakan tanaman sawi.

Tabel 6. Distribusi Petani Responden berdasarkan Luas lahan di Desa Baumata Timur

\begin{tabular}{|c|c|c|c|}
\hline No & Luas lahan (Are) & Jumlah (Orang) & Persentase (\%) \\
\hline 1 & $1-10$ & 22 & 53,66 \\
\hline 2 & $11-20$ & 19 & 46,34 \\
\hline & Jumlah & $\mathbf{4 1}$ & $\mathbf{1 0 0}$ \\
\hline
\end{tabular}

Sumber: Data primer 2020 (diolah)

Berdasarkan Tabel di atas diketahui 53,66 persen responden di lokasi penelitian memiliki lahan berkisar antara 1-10 are. sisanya sebanyak 19 orang petani memiliki luas lahan antara 11-20 are dengan presentase sebesar 46,34\%. Petani dengan luas lahan yang besar biasanya meningkatkan jumlah produksi dan pendapatan yang diperoleh oleh petani

\subsection{Biaya Produksi}

Biaya Tetap. Biaya tetap adalah biaya yang dikeluarkan selama proses produksi yang besarnya tidak dipengaruhi oleh banyaknya produksi yang dihasilkan, dan dinyatakan dalam satuan rupiah. Biaya tetap yang dalam penelitian ini merupakan biaya penyusutan peralatan. Penyusutan peralatan yang dihitung dalam penelitian ini adalah pacul, sprayer, parang, dan ember. Setiap petani responden mempunyai pacul, sprayer, parang dan embernya masing-masing, sehingga alat-alat tersebut perlu dihitung biaya penyusutannya. Alat-alat pertanian ini juga digunakan bersama dengan usahatani lainnya yang tidak diteliti dalam penelitian ini.

Berdasarkan hasil dari perhitungan rata-rata biaya penyusutan petani di Desa Baumata Timur Rp107.820/responden dan Rp9.863/are. Rata-rata biaya penyusutan tersebut terdiri atas rata-rata biaya penyusutan pacul sebesar Rp8.484/responden, rata-rata biaya penyusutan sprayer sebesar Rp79.383, rata-rata biaya penyusutan parang sebesar Rp7.760/responden dan rata-rata biaya penyusutan untuk ember sebesar Rp12.193/responden.

Biaya Variabel. Biaya variabel yang di keluarkan oleh petani berupa biaya benih, pupuk, pestisida, upah tenaga kerja, dan biaya transportasi.

Tabel 7. Komponen Biaya Variabel pada Usahatani sawi di Desa Baumata Timur Kecamatan Taebenu

\begin{tabular}{|c|c|c|c|c|c|}
\hline No & Biaya Variabel & Rata-Rata (Rp/resp) & Max (Rp) & Min (Rp) & Rata-Rata (Rp/are) \\
\hline 1 & Benih $(\mathrm{gr})$ & 530.732 & 1.280 .000 & 300.000 & 44.774 \\
\hline 2 & Pupuk $(\mathrm{kg})$ & 54.488 & 116.000 & 0 & 4.597 \\
\hline 3 & Pestisida $(\mathrm{kg})$ & 684.390 & 1.300 .000 & 400.000 & 57.737 \\
\hline 4 & Tenaga Kerja $(\mathrm{HKO})$ & 150.024 & 237.000 & 96.000 & 12.656 \\
\hline 5 & Transportasi & 10.000 & 10.000 & 10.000 & 844 \\
\hline & Total & $\mathbf{1 . 4 2 9 . 6 3 4}$ & $\mathbf{2 . 9 4 3 . 0 0 0}$ & $\mathbf{8 0 6 . 0 0 0}$ & $\mathbf{1 2 0 . 6 0 7}$ \\
\hline
\end{tabular}

Sumber : Data Primer Diolah (2020)

Berdasarkan data pada Tabel di atas dapat diketahui bahwa rata-rata biaya variabel sebesar Rp1.429.634/responden dan Rp120.607/are, yang terbagi atas rata-rata biaya benih sebesar Rp530.732/responden dan Rp44.774/are, rata-rata pupuk sebesar Rp54.488/responden dan Rp4.597/are, rata-rata pestisida sebesar Rp684.390/responden dan Rp57.737/are, rata-rata tenaga kerja sebesar Rp150.024/responden dan Rp12.656/are, dan rata-rata transportasi sebesar Rp10.000/responden dan Rp844/are.

Penerimaan. Penerimaan usahatani diperoleh dari jumlah produksi dikali dengan harga jual persatuan produksi. Harga yang dimaksud adalah harga ditingkat petani. Semakin besar jumlah produksi maka akan semakin besar penerimaan yang akan diperoleh. Sebaliknya, semakin rendah produksi maka akan semakin rendah pula penerimaannya. 
Tabel 8. Penerimaan Usahatani Sawi di Desa Baumata Timur

\begin{tabular}{|c|l|c|c|}
\hline No & \multicolumn{1}{|c|}{ Komponen } & Jumlah & Rata-rata per are \\
\hline 1 & Produksi (Kg) & 46.080 & 3.840 \\
\hline 2 & Harga Jual (Rp) & 5.000 & - \\
\hline 3 & Penerimaan (Rp/Resp) & 5.619 .512 & 468.293 \\
\hline
\end{tabular}

Sumber : Data Primer Diolah 2020

Berdasarkan Tabel di atas diketahui bahwa harga jual yang ditetapkan oleh petani sawi di Desa Baumata Timur adalah Rp5.000/kg dengan total produksi sawi adalah $46.080 \mathrm{~kg}$, dengan rata-rata 3.840 $\mathrm{kg} / \mathrm{are}$. Dari hasil analisa dapat dilihat total penerimaan sebesar Rp5.619.512/resp dengan rata-rata penerimaan yang diterima adalah sebesar Rp468.293/are.

Pendapatan. Pendapatan diperoleh dari selisih antara penerimaan dan biaya yang dikeluarkan petani dalam usahatani sawi. Total penerimaan yang diperoleh petani dalam usahatani sawi di Desa Baumata Timur sebesar Rp4.082.058/responden atau Rp340.172/are dengan pendapatan terbesar responden yaitu sebesar Rp5.420.150/are dan pendapatan terkecil sebesar Rp2.720.850/are.

\subsection{Analisis Penggunaan Faktoor-faktor Produksi Usahatani Sawi}

Penggunaan faktor-faktor produksi usahatani sawi di Desa Baumata Timur Kecamatan Taebenu Kabupaten Kupang dalam penelitian ini dibatasi pada penggunaan faktor produksi luas lahan (X1), benih (X2), pupuk organik (X3), pupuk anorganik (X4), pestisida (X5), dan tenaga kerja (X6). Kombinasi dari penggunaan faktor-faktor produksi ini kemudian menghasilkan produksi sawi (Y). Dalam penggunaannya, kombinasi dari faktor-faktor produksi tersebut akan menentukan meningkat atau menurunnnya hasil produksi sawi. Untuk mengetahui pengaruh dan dampak dari penggunaan faktorfaktor produksi sawi di Desa Baumata Timur Kecamatan Taebenu Kabupaten Kupang, maka dalam penelitian ini menggunakan analisis regresi linear berganda dengan fungsi produksi Cobb-Douglass. Dalam analisis ini, diketahui bahwa fungsi produksi memperlihatkan pengaruh dari berbagai variabel independen terhadap variabel dependen. Variabel dependen yang dimaksudkan disini adalah tingkat output atau produksi sawi, sedangkan variabel independen adalah penggunaan input atau faktor produksi usahatani sawi. Pengaruh penggunaan faktor-faktor produksi terhadap produksi sawi dapat dijelaskan pada tabel dibawah ini

Tabel 9. Hasil Analisis Regresi Fungsi Produksi Cobb-Douglass Usaha Tani Sawi Pada Desa Baumata 'Timur Kecamatan Taebenu Kabupaten Kupang

\begin{tabular}{|c|c|c|c|c|}
\hline Variabel & $\begin{array}{c}\text { Koefisien } \\
\text { Regresi }\end{array}$ & $\begin{array}{c}\text { Std. } \\
\text { Error }\end{array}$ & $\begin{array}{c}\mathrm{t}- \\
\text { hitung }\end{array}$ & Signifikansi \\
\hline Konstanta & 5,308 & 0,093 & 57,766 & 0,000 \\
\hline Luas Lahan (X1) & 0,395 & 0,047 & 8,396 & $0,000 * *$ \\
\hline Benih (X2) & 0,082 & 0,027 & 3,075 & $0,004 *$ \\
\hline Pupuk Organik (X3) & 0,079 & 0,049 & 1,619 & 0,115 \\
\hline $\begin{array}{l}\text { Pupuk Anorganik } \\
(\mathrm{X} 4)\end{array}$ & 0,065 & 0,30 & 2,125 & 0,041 \\
\hline Pestisida (X5) & $-0,035$ & 0,24 & $-1,487$ & 0,146 \\
\hline Tenaga Kerja (X6) & 0,002 & 0,14 & 0,154 & 0,879 \\
\hline \multicolumn{2}{|c|}{$\mathrm{R}^{2}=0,994$} & \multicolumn{3}{|c|}{$\mathrm{R}$ adjusted Square $=0,985$} \\
\hline \multicolumn{2}{|c|}{ F-hit $=441,015$} & \multicolumn{3}{|c|}{ Signifikansi $=0,000 * *$} \\
\hline \multicolumn{5}{|l|}{ Keterangan : } \\
\hline \multicolumn{5}{|c|}{$* *=$ signifikan pada $\alpha \leq 1 \%$} \\
\hline \multicolumn{5}{|c|}{$*=$ signifikan pada $\alpha \leq 5 \%$} \\
\hline
\end{tabular}

Berdasarkan tabel di atas, koefisien regresinya adalah:

$\mathrm{LnY}=5,308+0,395 \ln \mathrm{X}_{1}+0,082 \ln \mathrm{X}_{2}+0,079 \ln \mathrm{X}_{3}+0,065 \ln \mathrm{X}_{4}-0,035 \ln \mathrm{X}_{5}+0,002 \ln \mathrm{X}_{6}+\mathrm{u}$ 


\subsection{Uji Koefisien Determinasi $\left(\mathbf{R}^{2}\right)$}

Berdasarkan hasil analisis regresi linier berganda dalam penelitian ini, diperoleh nilai R2 sebesar 0,994. Berdasarkan hasil tersebut diketahui bahwa kemampuan variabel-variabel bebas untuk menjelaskan variabel terikat yakni sebesar 99,4\%. Sedangkan sisanya sebesar 0,6\% dijelaskan oleh variabel-variabel lain yang tidak dimasukan dalam model regresi. Nilai $0,6 \%$ ini mengartikan bahwa faktor-faktor yang tidak dimasukan dalam model penelitian berpengaruh terhadap produksi sawi. Faktor-faktor tersebut bisa saja iklim, suhu, atau manajemen usahatani yang perlu diteliti lebih lanjut.

\subsection{Uji Keragaman (Uji F)}

Uji $F$ digunakan untuk mengetahui tingkat keragaman dari beberapa variabel independen terhadap variabel dependen. Tujuannya yakni untuk melihat pengaruh dari kombinasi faktor-faktor produksi terhadap produksi sawi secara bersamaan. Hasil pengujian faktor-faktor produksi secara bersama-sama atau serempak menunjukan bahwa faktor-faktor produksi luas lahan (x1), benih (x2), pupuk organik (x3), pupuk anorganik (x4), pestisida (x5), dan tenaga kerja (x6) berpengaruh nyata terhadap produksi sawi $(\alpha 0,05)$. Uji $F$ hitung diperoleh nilai sebesar 441,015 sedangkan $F$ tabel sebesar 2,49. Dengan demikian F hitung > F tabel, sehingga dapat disimpulkan bahwa hipotesis ditolak, karena variabel independen secara bersama-sama berpengaruh nyata terhadap variabel dependen (Y) yaitu produksi sawi.

\subsection{Analisis Uji parsial (Uji T)}

\section{a.Luas Lahan (X1)}

Berdasarkan hasil analisis regresi diketahui bahwa faktor produksi luas lahan secara parsial berpengaruh sangat nyata terhadap produksi sawi $(\alpha 0,01)$, dengan nilai t hitung sebesar 8,396 , sedangkan nilai t tabel yakni 1,689. Sehingga tolak H0 dan terima H1. Nilai koefisien regresi sebesar 0,395. Nilai koefisien regresi tersebut mengartikan bahwa penambahan faktor produksi luas lahan sebesar $1 \%$ akan meningkatkan produksi sawi sebesar $0,395 \%$.

\section{b.Benih (X2)}

Berdasarkan hasil analisis regresi diketahui bahwa faktor produksi benih secara parsial berpengaruh sangat nyata terhadap produksi sawi $(\alpha 0,05)$, dengan nilai t hitung sebesar 3,075 , sedangkan nilai t tabel 1,689 , maka nilai t hitung > t tabel maka tolak H0 terima H1. Nilai koefisien regresi sebesar 0,082 . Nilai koefisien regresi tersebut mengartikan bahwa penambahan faktor produksi benih sebesar $1 \%$ akan meningkatkan produksi sawi sebesar $0,082 \%$. Rata-rata penggunaan benih di lokasi penelitian adalah 28 gr/are dengan lebar bedeng $100 \mathrm{~cm}$ dan jarak bedeng $30 \mathrm{~cm}$. Sedangkan anjuran penggunaan benih untuk penanaman dengan luas lahan satu are adalah 24,6 gr/are dengan lebar bedeng $100 \mathrm{~cm}$ dan dan jarak antar bedeng $25-35 \mathrm{~cm}$. Terlihat bahwa lebar bedeng, jarak tanam dan penggunaan faktor produksi benih sudah ideal.

\section{c.Pupuk Organik (X3)}

Berdasarkan hasil analisis regresi diketahui bahwa faktor produksi pupuk organik secara parsial tidak berpengaruh nyata terhadap produksi sawi $(\alpha 0,10)$, dengan nilai t hitung sebesar 1,619 , sedangkan nilai $\mathrm{t}$ tabel 1,689, maka nilai $\mathrm{t}$ hitung < $\mathrm{t}$ tabel maka terima $\mathrm{H} 0$ tolak $\mathrm{H} 1$. Nilai koefisien regresi sebesar 0,079 . Nilai koefisien regresi tersebut mengartikan bahwa penambahan pupuk organik sebesar $1 \%$ akan menurunkan produksi sawi sebesar $0,079 \%$. Rata-rata penggunaan pupuk organik di lokasi penelitian adalah $32 \mathrm{~kg} /$ are, sedangkan penggunaan pupuk organik yang ideal untuk penanaman satu are luas lahan adalah 70,20 kg/are. Hal ini menunjukan bahwa penggunaan pupuk organik yang dilakukan petani responden masih kurang dari penggunaan pupuk organik yang idea.

\section{d.Pupuk Anorganik (X4)}

Berdasarkan hasil analisis regresi diketahui bahwa faktor produksi pupuk anorganik secara parsial berpengaruh nyata terhadap produksi sawi $(\alpha 0,10)$, dengan nilai t hitung sebesar 2,125 , sedangkan nilai $\mathrm{t}$ tabel 1,689, maka nilai $\mathrm{t}$ hitung $>\mathrm{t}$ tabel maka tolak $\mathrm{H} 0$ terima H1. Nilai koefisien regresi sebesar 0,065 . Nilai koefisien regresi tersebut mengartikan bahwa penambahan pupuk anorganik sebesar $1 \%$ akan meningkatkan produksi sawi sebesar $0,065 \%$. Rata-rata penggunaan pupuk anorganik di lokasi penelitian adalah $32 \mathrm{~kg} / \mathrm{are}$, sedangkan penggunaan pupuk anorganik yang ideal untuk penanaman satu are luas lahan adalah $2,94 \mathrm{~kg} / \mathrm{are}$. Artinya penggunaan pupuk anorganik di lokasi penelitian melebihi penggunaan faktor produksi pupuk anorganik yang ideal.

\section{e.Pestisida (X5)}

Berdasarkan hasil analisis regresi diketahui bahwa faktor produksi pestisida secara parsial tidak berpengaruh nyata terhadap produksi sawi $(\alpha 0,10)$, dengan nilai t hitung sebesar $-1,487$ sedangkan nilai 
$\mathrm{t}$ tabel 1,689, maka nilai t hitung < t tabel maka terima $\mathrm{H} 0$ dan tolak $\mathrm{H} 1$. Nilai koefisien regresi sebesar $-0,035$. Nilai koefisien regresi tersebut mengartikan bahwa bertambahnya jumlah pestisida sebesar $1 \%$ akan menurunkan produksi sawi sebesar $0,035 \%$. Rata-rata penggunaan pestisida di lokasi penelitian adalah 6 liter/are, sedangkan penggunaan pestisida yang ideal untuk penanaman satu are luas lahan adalah 1,73 liter/are. Artinya penggunaan faktor produksi pestisida pada usahatani sawi sudah melebihi ideal. Penggunaan pestisida yang berlebihan dapat merusak tanaman dan hewan-hewan kecil yang baik bagi tanaman. Oleh karena itu penggunaan pestisida yang berlebihan dapat menurunkan produksi sawi di lokasi penelitian.

\section{f.Tenaga Kerja (X6)}

Berdasarkan hasil analisis regresi diketahui bahwa faktor produksi tenaga kerja secara parsial tidak berpengaruh nyata terhadap produksi sawi dengan nilai $t$ hitung sebesar 0,154 sedangkan nilai $t$ tabel 1,689, dengan demikian nilai $\mathrm{t}$ hitung < $\mathrm{t}$ tabel maka terima $\mathrm{H} 0$ dan tolak $\mathrm{H} 1$. Nilai koefisien regresi sebesar 0,002. Nilai koefisien regresi tersebut mengartikan bahwa ada kecenderungan setiap peningkatan penggunaan tenaga kerja sebesar $1 \%$ maka akan menurunkan produksi sawi sebesar $0,002 \%$. Rata-rata penggunaan tenaga kerja di lokasi penelitian mulai dari kegiatan pengolahan lahan, penanaman, penyiangan, pemupukan, panen dan pasca panen adalah $605 \mathrm{HKO}$ per are.

\subsection{Efisiensi Teknis Usahatani Sawi di Lokasi Penelitian}

Efisiensi teknis secara keseluruhan dalam fungsi produksi Cobb-Douglass tercermin pada nilai atau parameter b0. Semakin besar nilai b0 maka tingkat efisiensi dari produksi usahatani semakin baik. Begitupun sebaliknya bila nilai b0 rendah berarti tingkat efisiensi dari produksi usahatani secara keseluruhan rendah. Berdasarkan nilai koefisien regresi dari fungsi produksi Cobb-Douglass, nilai koefisiensinya selain mencerminkan parameter koefisien elastisitas juga mencerminkan tingkat efisiensi secara teknis dari penggunaan faktor-faktor produksi sawi yang digunakan. Analisis tingkat efisiensi teknis pada usahatani sawi bertujuan untuk mengetahui tingkat efisiensi tertinggi dan efisiensi terendah yang dicapai petani dalam berusahatani sawi di Desa Baumata Timur.

Tabel 10. Estimasi Fungsi Produksi Cobb-Douglass Usahatani Sawi di Lokasi Penelitian

\begin{tabular}{|c|l|c|}
\hline \multirow{2}{*}{ No } & \multicolumn{1}{|c|}{ Variabel } & Koefisien Regresi (bi) \\
\cline { 2 - 3 } & Konstanta & 5,308 \\
\hline 1 & Luas Lahan (X1) & 0,395 \\
\hline 2 & Benih (X2) & 0,082 \\
\hline 3 & Pupuk Organik (X3) & 0,079 \\
\hline 4 & Pupuk Anorganik (X4) & 0,065 \\
\hline 5 & Pestisida (X5) & $-0,035$ \\
\hline 6 & Tenaga Kerja (X6) & 0,002 \\
\hline
\end{tabular}

Sumber: Data Primer Diolah, (2020)

Sifat fungsi produksi selalu diasumsikan mengikuti hukum kenaikan hasil yang berkurang atau The Law of Diminishing Return. Hukum ini menyatakan bahwa jika penggunaan input-input lainnya tetap maka tambahan output yang dihasilkan dari setiap tambahan satu unit input yang ditambahkan tadi mula-mula naik tetapi kemudian seterusnya ketika mencapai suatu titik tertentu akan menurun jika input tersebut terus ditambahkan (Suratiyah, 2006).

Gambar Elastisitas Faktor Produksi Sawi 


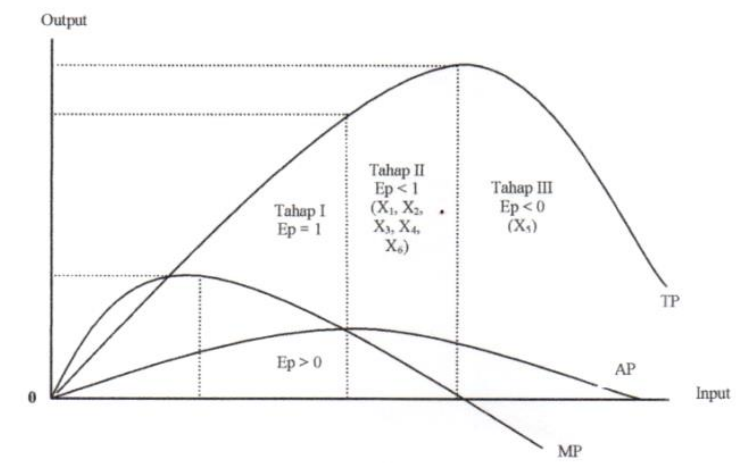

Sumber: Suratiyah, 2006

Dengan menggunakan gambar di atas, dapat dilihat tiga tahapan produksi yakni, tahapan I, tahapan II dan tahapan III. Pada tahapan produksi yang pertama, produk rata-rata dari input variabel terus meningkat dimana MP > AP. Pada tahapan II, MP < AP sehingga produk rata-rata menurun, seiring dengan produk marginal, namun produk marginal masih bernilai positif sehingga total produksi masih terus meningkat. Sedangkan pada tahapan III, produk marjinal sudah bernilai negatif sehingga produk rata-rata terus menurun, bersamaan dengan penurunan produk total dan marginal. Sehingga satu satuan input yang digunakan akan mengurangi output yang dihasilkan.

a.Luas Lahan (X1)

Berdasarkan hasil analisis regresi linier berganda diperoleh nilai koefisien regresi dari luas lahan sebesar 0,395 . Koefisien regresi tersebut bernilai positif sehingga berada diantara $0 \leq \mathrm{b} 1 \leq 1$, sehingga nilai tersebut menunjukan bahwa penggunaan luas lahan di daerah penelitian berada pada daerah produksi rasional (daerah II), sehingga secara teknis penggunaan faktor produksi luas lahan dapat dimanfaatkan secara efisien

b.Benih (X2)

Berdasarkan hasil analisis regresi linier berganda diperoleh nilai koefisien regresi dari benih sebesar 0,082 . Koefisien regresi tersebut bernilai positif sehingga berada diantara $0 \leq \mathrm{b} 2 \leq 1$, sehingga nilai tersebut menunjukan bahwa penggunaan benih di daerah penelitian berada pada daerah produksi rasional (daerah II), sehingga secara teknis penggunaan faktor produksi benih dapat dimanfaatkan secara efisien.

c.Pupuk Organik (X3)

Berdasarkan hasil analisis regresi linier berganda diperoleh nilai koefisien regresi dari pupuk organik sebesar 0,079 . Koefisien regresi tersebut bernilai positif sehingga berada diantara $0 \leq b 3 \leq 1$, sehingga nilai tersebut menunjukan bahwa penggunaan pupuk organik di daerah penelitian berada pada daerah produksi rasional (daerah II), sehingga secara teknis penggunaan faktor produksi pupuk organik sudah dimanfaatkan secara efisien.

d.Pupuk Anorganik (X4)

Berdasarkan hasil analisis regresi linier berganda diperoleh nilai koefisien regresi dari pupuk anorganik sebesar 0,395 . Koefisien regresi tersebut bernilai positif sehingga berada diantara $0 \leq b 4 \leq 1$, sehingga nilai tersebut menunjukan bahwa penggunaan pupuk anorganik di daerah penelitian berada pada daerah produksi rasional (daerah II), sehingga secara teknis penggunaan faktor produksi pupuk anorganik dapat dimanfaatkan secara efisien.

e.Pestisida (X5)

Berdasarkan hasil analisis regresi linier berganda diperoleh nilai koefisien regresi dari luas lahan sebesar $-0,035$. Koefisien regresi tersebut bernilai negatif sehingga berada di daerah irrasional (daerah III) dengan nilai koefisien regresinya berda pada $\mathrm{Ep}<0$, sehingga secara teknis penggunaan faktor produksi pestisida untuk kegiatan usahatani sawi di daerah penelitian tidak efisien. Apabila penggunaan faktor produksi pestisida semakinn bertambah, maka akan menyebabkan terjadinya penurunan produksi sawi. Maka dari itu penggunaan pestisida perlu dikurangi.

f.Tenaga Kerja (X6)

Berdasarkan hasil analisis regresi linier berganda diperoleh nilai koefisien regresi dari tenaga kerja sebesar 0,002 . Koefisien regresi tersebut bernilai positif sehingga berada diantara $0 \leq \mathrm{b} 6 \leq 1$, sehingga nilai tersebut menunjukan bahwa penggunaan tenga kerja di daerah penelitian berada pada daerah 
produksi rasional (daerah II), sehingga secara teknis penggunaan faktor produksi tenaga kerja dapat dimanfaatkan secara efisien.

\subsection{Analisis R/C Ratio Usahatani Sawi di Lokasi Penelitian}

Untuk mengetahui keuntungan relatif dari usahatani sawi di lokasi penelitian, maka dapat dihitung dengan menggunakan analisis $\mathrm{R} / \mathrm{C}$ ratio dimana dapat membandingkan semua penerimaan dengan semua biaya yang dikeluarkan dalam usahatani, (Soeriadmadja, 1989) yakni sebagai berikut:

$$
\mathrm{R} / \mathrm{C}=\frac{\text { Revenue }}{\text { Cost }}
$$

Kriteria yang digunakan adalah:

$>$ Jika $\mathrm{R} / \mathrm{C}$ ratio $>1$ maka usahatani sawi menguntungkan

$>$ Jika $\mathrm{R} / \mathrm{C}$ ratio $<1$ maka usahatani sawi tidak menguntungkan

$>$ Jika $\mathrm{R} / \mathrm{C}$ ratio $=1$ maka usahatani sawi tidak untung dan tidak rugi

Total penerimaan petani responden dalam usahatani sawi di lokasi penelitian adalah sebesar Rp 230.400.000 dengan total pengeluaran sebesar Rp 63.035.620. berdasarkan penjelasan di atas maka perhitungan $\mathrm{R} / \mathrm{C}$ ratio untuk usahatani sawi adalah sebagai berikut:

$$
\begin{aligned}
* \mathrm{R} / \mathrm{C} & =\frac{\text { Revenue }}{\text { Cost }} \\
* \quad \mathrm{R} / \mathrm{C} & =\frac{230.400 .000}{63.035 .620} \\
* \quad \mathrm{R} / \mathrm{C} & =3,65
\end{aligned}
$$

Nilai $\mathrm{R} / \mathrm{C}$ ratio untuk usahatani sawi di lokasi penelitian berdasarkan hasil analisis adalah 3,65. Hal tersebut dapat diartikan bahwa untuk setiap investasi Rp 1000 pada kegiatan usahatani sawi akan memberikan penerimaan pada akhir kegiatan sebesar Rp 3.650. Hal ini berarti usahatani sawi menguntungkan secara ekonomi.

\section{KESIMPULAN}

Berdasarkan hasil pembahasan dan analisis terhadap kegiatan penelitian yang dilakukan di Desa Baumata Timur Kecamatan Taebenu Kabupaten Kupang, maka dapat disimpulkan sebagai berikut:

1. Penggunaan faktor produksi secara serempak berpengaruh nyata terhadap hasil produksi sawi, sedangkan secara parsial faktor produksi yang berpengaruh sangat nyata terhadap peningkatan produksi adalah luas lahan, benih, dan pupuk anorganik. Sedangkan faktor produksi lainnya yaitu pupuk organik, pestisida dan tenaga kerja tidak berpengaruh nyata terhadap produksi sawi di lokasi penelitian.

2. Penggunaan faktor-faktor produksi seperti luas lahan, benih, pupuk organik, pupuk anorganik dan tenaga kerja dalam usahatani sawi secara teknis telah dimanfaatkan secara efisien, karena nilai $b$ > 0 . Sedangkan faktor produksi pestisida dalam usahatani sawi secara teknis tidak efisien, karena nilai $\mathrm{b}<0$.

3. Usahatani sawi di lokasi penelitian memberikan keuntungan relatif dengan nilai $\mathrm{R} / \mathrm{C}$ ratio $>1$ yakni 3,65 sehingga usahatani sawi layak untuk diusahakan.

\section{DAFTAR PUSTAKA}

Agustira, M.A., 2004. Analisis Optimasi Penggunaan Input Produksi Pada Usahatani Padi Sawah di Kabupaten Deli Serdang. Skripsi. Fakultas Pertanian Universitas Sumatera Utara, Medan.

Dakar Marianus, 2016. Efisiensi Teknis Usahatani Jagung (Zea Mays) Pada Zona IIIay di Timor Barat. Skripsi Fakultas Pertanian Undana.

Hane, A. Kune, S.J. 2018. Analisis Pendapatan Usahatani Sawi di Kawasan Ekonomi Masyarakat Desa Bannae Kecamatan Insana Barat Kabupaten Timor Tengah Utara. Jurnal Agribisnis Lahan Kering Agrimor 1 (2), 27-29.

Lama, M. Kune, S.J. 2016. Faktor-Faktor yang Mempengaruhi Produksi Usaha Tani Sayur Sawi di Kelurahan Bensone Kecamatan Kota Kefamenanu Kabupaten Timor Tengah Utara. Jurnal Agribisnis Lahan Kering Agrimor 1 (2), 27-29.

Lutfi M., Baladina Nur, 2018. Analisis efisiensi teknis penggunaan faktor produksi pada usahatani tembakau (Studi kasus di Desa Polagan Kecamatan Galis Kabupaten Pamekasan). Jurnal 
Ekonomi Pertanian dan Agribisnis (JEPA) Volume 2, Nomor 3 (2018) : 226-233. Fakultas Pertanian Universitas Brawijaya.

Opat, E. Hutapea A. N. 2017. Analisis Pendapatan Usahatani Sawi Manis di Kelurahan Oelami, Kecamatan Bikomi Selatan, Kabupaten Timor Tengah Utara. Jurnal Agribisnis Lahan Kering Agrimor 2 (3), 33-35.

Rahayu, Nevi. 2004. Analisis Efisiensi Teknis dan Efisiensi Ekonomi Usahatani Padi Kabupaten Teras. Jurnal Fakultas Pertanian Universitas Negeri Solo.

Rahmat, Nur Alam, Kalaba Yulianti. 2017. Analisis Efisiensi Penggunaan Input Produksi Pada Usahatani Padi Sawah. Jurnal Agrotekbis (1) : 199-126. Fakultas Pertanian Universitas Tadulako, Palu.

Rahmi, A. (2014). Faktor-Faktor Yang Mempengaruhi Produksi Sawi Di Kecamatan Kuala Kabupaten Nagan Raya. Universitas Teuku Umar.

Rukmana, R. 2005. Bertanam Sayuran di Pekarangan. Kanisius, Yogyakarta. Direktorat Gizi Departemen Kesehatan RI, 1981. Daftar Komposisi Bahan Makanan. Bhatara Karya Aksara, Jakarta

Soekartawi (a). 1994. Teori Ekonomi Produksi. Raja Grafindo Persada, Jakarta.

Soekartawi (b). 2002. Prinsip Dasar Ekonomi Pertanian. Raja Grafindo Persada, Jakarta.

Soekartawi (c). 1994. Analisis Usahatani. Penerbit Universitas Indonesia (UI-Press). Jakarta.

Soeriatmadja, 1989. Kelayakan Usahatani. Graha Ilmu, Yogjakarta.

Soetrisno, L., 1999. Pertanian pada Abad Ke-21. Direktorat Jenderal Pendidikan Tinggi. Departemen Pendidikan dan Kebudayaan, Jakarta.

Tarigan, K., dan L. Sihombing. 2007. Ekonomi Produksi Pertanian. USU-Press, Medan. 